\title{
Otimização da técnica da PCR para a deteç̧ão de Actinobacillus pleuropneumoniae
}

\author{
Optimization of PCR technique for detection of Actinobacillus pleuropneumoniae
}

\author{
Karina Koerich de Souza ${ }^{\mathrm{I}}$ Catia Silene Klein ${ }^{\mathrm{II}}{ }^{*}$ Jalusa Deon Kich"I Arlei Coldebella ${ }^{\mathrm{II}}$ \\ Geraldo Camilo Alberton ${ }^{\mathrm{I}}$
}

\section{RESUMO}

A utilização de métodos moleculares baseados em PCR é fundamental na deteç̧ão do Actinobacillus pleuropneumoniae, sendo capaz de identificar a infecção antes do estabelecimento da doença no rebanho. Estes métodos apresentam maior sensibilidade quando comparados com métodos tradicionais de isolamento bacteriano, mas podem sofrer influência de substâncias que reduzem a especificidade do teste e proporcionam o aparecimento de amplificações inespecíficas. No intuito de reduzir as amplificações inespecíficas, observadas quando aplicada a PCR para o gene cpx em amostras de tecido tonsilar, procedeu-se a otimização da técnica, na qual foram analisados o efeito do pré-cultivo bacteriano e as diferentes temperaturas de anelamento dos iniciadores e foi introduzido, no protocolo, um anticorpo que se liga na enzima Taq DNA Polimerase, aumentando a especificidade do teste. Paralelamente, foi realizado um experimento para verificar o efeito inibidor do tecido tonsilar sobre os resultados da PCR. Para isso, porções de tonsila de animais negativos para A. pleuropneumoniae foram contaminadas artificialmente com a amostra referência do sorotipo 5B. A adição do anticorpo para a enzima Taq DNA Polimerase e o aumento da temperatura de anelamento dos iniciadores para $57^{\circ} \mathrm{C}$ diminuiu o aparecimento de amplificações inespecíficas. Os resultados obtidos no experimento demonstraram que o tecido tonsilar possui efeito inibidor nas amplificações da PCR. Além disso, a amplificação depende de, no mínimo, 675 UFC presentes na alíquota da amostra usada na PCR (equivalente a 1,35 × $10^{5}$ UFC $\mathrm{mL}^{-1}$ ), assim, amostras de fragmentos de tecido de infecções iniciais e/ou com poucas células podem apresentar resultados falsos negativos.

Palavras-chave: $P C R$, gene $c p x$, tonsila, Actinobacillus pleuropneumoniae, pleuropneumonia suína.

\begin{abstract}
The use of molecular methods based on PCR is important in Actinobacillus pleuropneumoniae detection, being able to identify the infection before the establishment of the disease in the herd. These methods have larger sensitivity when compared with traditional methods of bacteriological isolation, but they can suffer influence of substances that reduce the specificity of the test and resulting in inespecific amplifications. In order to reduce inespecific amplifications, observed when applied the PCR technique for the gene cpx in tonsil's tissue samples, the optimization was performed, in which different annealing temperatures were analyzed and introduced, in the technique, an antibody that binds to the enzyme Taq DNA Polimerase, increasing its specificity. In parallel, an experiment was performed in order to verify the inhibiting effect of the tonsil's tissue on the PCR results. For that, portions of tonsil from animals negative to the A. pleuropneumoniae were artificially contaminated with the reference sample of the sorotype 5B. The addition antibody for the enzyme Taq DNA Polimerase and the increase of the primers anneling temperature to $57^{\circ} \mathrm{C}$ reduced the inespecific amplifications. The results obtained in the experiment demonstrated a possible inhibiting effect of the tonsil's tissue in the PCR amplifications. Besides, amplifications depend on at least 675 UFC present in the aliquot of samples that will be used in PCR (equivalent to $1.35 \times 10^{5}$ UFC $\mathrm{mL}^{-1}$ ), therefore, samples tissue's fragments in initial infections and/or with few cells can result in false-negative.
\end{abstract}

Key words: $P C R$, gene cpx, tonsilar tissue, Actinobacillus pleuropneumoniae, porcine pleuropneumonia.

\section{INTRODUÇÃO}

A pleuropneumonia suína é uma doença infectocontagiosa específica dos suínos, causada pela

IDepartamento de Medicina Veterinária, Curso de Pós-graduação em Ciências Veterinárias, Universidade Federal do Paraná (UFPR), Curitiba, PR, Brasil.

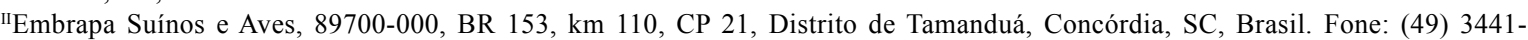
0400/Fax: (49) 3442-8559. E-mail: catia@cnpsa.embrapa.br. *Autor para correspondência. 
bactéria Actinobacillus pleuropneumoniae (FENWICK e HENRY, 1994). As lesões decorrentes da pleuropneumonia são restritas à cavidade torácica, envolvendo pulmões, pleura e, com freqüência, pericárdio (MORES et al., 1984). A doença pode cursar com quadro superagudo, agudo, subagudo ou crônico. Os animais que sobrevivem à infecção aguda de pleuropneumonia tornam-se portadores do agente, abrigando o A.pleuropneumoniae no trato respiratório, principalmente nas tonsilas e, de modo menos freqüente, na cavidade nasal (NICOLET, 1992; SIDIBÉ et al., 1993). Rebanhos afetados pela pleuropneumonia apresentam consideráveis prejuízos econômicos, principalmente pela redução no ganho de peso diário, pela piora na conversão alimentar, pelas despesas com medicação, vacinação, serviços veterinários e pela condenação de carcaças no abatedouro (HUNNEMAN, 1986).

Técnicas moleculares para o diagnóstico da pleuropneumonia, como a Reação em Cadeia da Polimerase (PCR), são ferramentas promissoras para um rápido diagnóstico etiológico, oferecendo várias vantagens quando comparada com testes utilizados na rotina de laboratório (MURDOCH, 2003). A PCR baseada no gene $c p x$, responsável pelo transporte de cápsula, permite a amplifcação de todos os sorotipos do A. pleuropneumoniae, exceto o sorotipo 4. No Brasil, onde há poucos dados sobre o isolamento do sorotipo 4 causando pleuropneumonia, sua aplicação é uma boa alternativa para o diagnóstico e para definir o status da granja (KLEIN et al., 2003).

A técnica de PCR utilizando como alvo o gene cpx foi otimizada e aplicada em isolados de A. pleuropneumoniae de casos clínicos brasileiros por KLEIN et al. (2003). Posteriormente, KUCHIISHI (2003) adaptou a metodologia para amostras biológicas de suínos com infecção experimental e natural. Nesta fase do estudo foram observadas amplificações inespecíficas e baixa sensibilidade, necessitando de novos estudos. Com o objetivo de adequar a técnica e reduzir as amplificações inespecíficas observadas quando aplicada em amostras de biopsia tonsilar, o teste de PCRcpx foi otimizado. Foi avaliada a interferência do tecido tonsilar na sensibilidade do teste, analisadas diferentes temperaturas de anelamento dos iniciadores e foi utilizado um anticorpo para a enzima Taq DNA Polimerase para aumentar a especificidade do teste.

\section{MATERIAL E MÉTODOS}

Contaminação experimental de tecido tonsilar $\mathrm{O}$ efeito inibidor do tecido tonsilar sobre os resultados da PCRcpx foi avaliado por um experimento de contaminação artificial de tonsilas com suspensão do cultivo de A.pleuropneumoniae sorotipo 5B padronizado para conter $1,5 \times 10^{9}$ de Unidades Formadoras de Colônias por $\mathrm{mL}\left(\mathrm{UFC} \mathrm{mL}^{-1}\right.$ ) e com posterior diluição na base 10. As tonsilas foram extraídas de dois suínos Specific Pathogen Free (SPF) negativos no teste de ELISA para antígeno lipopolissacarídeo cadeia longa (LPS-CL) polivalente para os sorotipos 3, 5 e 7 de A.pleuropneumoniae (MACHADO et al., 2001). Tais tonsilas apresentaram resultados negativos no isolamento bacteriológico tradicional (IBT) e na PCRcpx para A.pleuropneumoniae sem etapa de préenriquecimento.

Neste experimento (Tabela 1), foram testadas duas variáveis: quantidade de tecido tonsilar de 1, 2 e 3 porções coletadas com pinça de biopsia e concentração inicial de células a partir de suspensões bacterianas nas concentrações de $1,9 \times 10^{6} \mathrm{e}$ $1,9 \times 10^{3} \mathrm{UFC} \mathrm{mL}^{-1} \mathrm{de} A$. pleuropneumoniae sorotipo 5B. Além dos tratamentos controles (T1, T2 e T3), o experimento teve o delineamento fatorial 3 x 3 (T4 ao T12), conforme segue: $\mathrm{T} 1$ ( $\mathrm{NaCl} 0,85 \%$ - salina estéril) como controle negativo; T2 e T3, sendo adicionados $100 \mu \mathrm{L}$ das suspensões bacterianas de $1,9 \times 10^{6} \mathrm{e}$ $1,9 \times 10^{3} \mathrm{UFC} \mathrm{mL}^{-1}$, respectivamente, como controles positivos; T4, T5 e T6 (uma, duas e três porções de tonsila, respectivamente), todos com salina estéril; T7, T8 e T9 (uma, duas e três porções de tonsila, respectivamente), cada porção de tonsila foi contaminada artificialmente com $100 \mu \mathrm{L}$ da suspensão de 1,9 x $10^{6} \mathrm{UFC} \mathrm{mL}^{-1}$; T10, T11 e T12 (uma, duas e três porções de tonsila, respectivamente), cada porção de tonsila foi contaminada artificialmente com $100 \mu \mathrm{L}$ da suspensão $1,9 \times 10^{3} \mathrm{UFC} \mathrm{mL}^{-1}$. Foram realizadas 10 repetições por tratamento.

As porções de tonsila foram maceradas, armazenadas em microtubos, e acrescidas de $100 \mu \mathrm{L}$ de solução salina ou das suspensões bacterianas por porção, de acordo com o tratamento (Tabela 1), nas quais permaneceram por 30 minutos a $37^{\circ} \mathrm{C}$ para possibilitar o contato da bactéria com o tecido, incluindo os tratamentos controles (T1, T2 e T3). Posteriormente, foram adicionados a $5 \mathrm{~mL}$ de caldo seletivo Lincomicina-Bacitracina (LB) (PIJOAN et al., 1983) e incubados a $37^{\circ} \mathrm{C}$ por 24 horas, como uma etapa de pré-enriquecimento para aumentar a população original e possibilitar a detecção do A. pleuropneumoniae, caso haja quantidade de bactérias abaixo do limite de detecção na amostra original. A concentração anterior à incubação em caldo $\mathrm{LB} / \mathrm{mL}$, desconsiderando o período de contato entre tecido tonsilar e suspensão bacteriana $\left(30 \mathrm{~min}\right.$ a $\left.37^{\circ} \mathrm{C}\right)$ 
em alguns tratamentos foi estimada como segue: $\mathrm{T} 2=3,8 \times 10^{4} \mathrm{UFC} \mathrm{mL}^{-1}$; $\mathrm{T} 3=3,8 \times 10^{1} \mathrm{UFC} \mathrm{mL}^{-1}$ $\mathrm{T} 7=3,8 \times 10^{4} \mathrm{UFC} \mathrm{mL}^{-1} ; \mathrm{T} 8=7,6 \times 10^{4} \mathrm{UFC} \mathrm{mL}^{-1}$; $\mathrm{T} 9=1,1 \times 10^{5} \mathrm{UFC} \mathrm{mL}^{-1}$; T10=3,8 X $10^{1} \mathrm{UFC} \mathrm{mL}^{-1}$; $\mathrm{T} 11=7,6 \times 10^{1} \mathrm{UFC} \mathrm{mL}^{-1} \mathrm{eT} 12=1,1 \times 10^{2} \mathrm{UFC} \mathrm{mL}^{-1}$.Após o período de incubação, foi extraído DNA de $1 \mathrm{ml}$ do cultivo de cada tratamento e realizada PCR para o gene срх.

Condições do teste

A otimização da PCRcpx foi realizada na Embrapa Suínos e Aves, onde 13 amostras padrão de A. pleuropneumoniae, representando os sorotipos um ao 12 (incluindo 5A e 5B), foram submetidas a quatro diferentes temperaturas de anelamento dos iniciadores, sendo estas a $54,55,56$ e $57^{\circ} \mathrm{C}$. As demais condições do teste foram de acordo com KLEIN et al. (2003).

$A$ adição de um anticorpo que se liga na enzima Taq DNA Polimerase foi testada pela comparação em sete amostras de biopsia tonsilar provenientes da mesma tonsila, coletadas com pinça de biopsia, onde cada porção de tonsila foi artificialmente contaminada com $100 \mu \mathrm{L}$ de uma suspensão do cultivo de A. pleuropneumoniae sorotipo 5B contendo aproximadamente 1,9 x 105UFC (dados não mostrados).

A técnica de extração do DNA de A. pleuropneumoniae utilizada em todas as etapas foi descrita por FAN et al. (1995) e modificada por KUCHIISHI (2003) e os iniciadores para o gene $c p x$ foram definidos por LO et al. (1998). A reação para um volume final de $25 \mu \mathrm{L}$ foi padronizada para conter: $5 \mu \mathrm{L}$ de amostra de DNA; $10 \mathrm{mM}$ de Tris- $\mathrm{HCl}$ (pH 8,3); 50mM de $\mathrm{KCl} ; 2,5 \mathrm{mM}$ de $\mathrm{MgCl}_{2} ; 200 \mu \mathrm{M}$ de cada desoxinucleotídeo trifosfatado (dNTP's); 30pmol de cada iniciador $c p x ; 0,2 \mu \mathrm{L}$ ( 1 Unidade) de enzima Taq DNA polimerase; $0,2 \mu \mathrm{L}$ de anticorpo da Taq DNA Polimerase (Platinum ${ }^{\circledR}$ Taq Antibody, Invitrogen ${ }^{\mathrm{TM}}$ Life Technologies).

O processo de amplificação foi realizado em termociclador (Mastercycler ${ }^{\circledR}$ Gradiente, Eppendorf) nas seguintes condições de temperatura e tempo: o DNA foi desnaturado com uma etapa a $94^{\circ} \mathrm{C}$ por cinco minutos e amplificado por 30 ciclos consistindo de desnaturação a $94^{\circ} \mathrm{C}$ por um minuto, anelamento dos iniciadores de acordo com as temperaturas testadas $\left(54\right.$ a $57^{\circ} \mathrm{C}$ ) por 45 segundos e polimerização a $72^{\circ} \mathrm{C}$ por dois minutos. Depois de completados os 30 ciclos, uma etapa final consistia de anelamento por cinco minutos e polimerização a $72^{\circ} \mathrm{C}$ por 10 minutos. A cada teste realizado, foram adicionados um controle positivo (amostra referência de A. pleuropneumoniae) e um controle negativo (reação de PCR sem DNA).
Após amplificação em termociclador, $6 \mu \mathrm{L}$ das amostras foram submetidas à separação por eletroforese, por aproximadamente 60 minutos, em gel de agarose na concentração de $1,5 \%$ corado com brometo de etídio $\left(0,5 \mu \mathrm{g} \mathrm{mL} \mathrm{m}^{-1}\right)$ (TAYLOR, 1993). Paralelamente às amostras, um marcador de peso molecular de $100 \mathrm{pb}$ foi aplicado. O tampão Tris-EDTAácido bórico (TBE) na concentração de $1 \mathrm{X}$ foi utilizado para a corrida eletroforética (SAMBROOK e RUSSELL, 2001). Os produtos resultantes da amplificação foram visualizados sob luz ultravioleta e fotodocumentados para análise.

Determinação da sensibilidade e especificidade do teste

O teste de sensibilidade, para determinar a concentração mínima de bactérias presentes para contagem e determinação das UFC $\mathrm{mL}^{-1}$, foi realizado utilizando a amostra referência de $A$. pleuropneumoniae sorotipo 5A, sendo cultivada em meio agar Nicolet. Após o cultivo, as diluições bacterianas foram realizadas em solução salina a partir da concentração inicial referente ao tubo 5 da escala MacFarland (equivalente a $1,5 \times 10^{9} \mathrm{UFC}^{-1}$ ) e foram realizadas diluições seriadas na base 10 até $10^{-12}$. Em seguida, $100 \mu \mathrm{L}$ de cada diluição foram semeados em três placas de Petri contendo meio de cultura agar Nicolet. As placas foram incubadas a $37^{\circ} \mathrm{C}$ por 18 horas em condição microaerófila para posterior contagem das UFC. Paralelamente, de cada diluição da suspensão bacteriana, foi retirado $1 \mathrm{~mL}$ para extração de DNA e realização da PCR, sem etapa de pré-enriquecimento.

No teste de especificidade da PCR $c p x$, foram utilizadas as seguintes amostras de bactérias presentes no trato respiratório dos suínos, tanto patogênicas como não-patogênicas, que podem interferir no teste diagnóstico: A. minor, Bordetella bronchiseptica, Haemophilus parasuis, A. porcinus, Pasteurella multocida, Staphylococcus aureus e Streptococcus suis (KLEIN et al., 2003) e foi incluído isolado de campo de $A$. indolicus, pertencente à bacterioteca da Embrapa Suínos e Aves.

Seqüenciamento do produto amplificado por PCRcpx Um fragmento de DNA de $715 \mathrm{pb}$ amplificado por PCR $c p x$ a partir de um isolado de campo, purificado de gel de agarose pelo kit Concert ${ }^{\mathrm{TM}}$ Nucleic Acid Purification System (Invitrogen ${ }^{\mathrm{TM}}$ Life Technologies), foi seqüenciado. A reação de seqüenciamento foi realizada com o kit Big Dye ${ }^{\mathrm{TM}}$ Terminator Cycle Sequencing Ready Reaction 3.0 v (Applied Biosystems - ABI) e após amplificação do DNA, $2 \mu \mathrm{L}$ da reação foram submetidos à eletroforese no seqüenciador $A B I P R I S M^{\circledR}$ 
377 DNA Sequencers (ABI). As condições do preparo da amostra foram realizadas de acordo com as recomendações do fabricante do kit e do equipamento. Após seqüenciamento do DNA, a leitura foi comparada com o banco de dados GenBank ${ }^{\circledR}$ (GENBANK OVERWIEW), por meio da ferramenta Basic Local Alignment and Search Tool (BLAST), para verificar o grau de similaridade desse isolado com as seqüências depositadas.

\section{RESULTADOS E DISCUSSÃO}

Entre os procedimentos adotados na otimização da PCRcpx, a temperatura de $57^{\circ} \mathrm{C}$ para anelamento dos iniciadores minimizou a amplificação de bandas inespecíficas. A otimização da PCRcpx permitiu a amplificação de um produto de $715 \mathrm{pb}$ em todas as amostras referência de A. pleuropneumoniae, exceto o sorotipo 4, como observado por $\mathrm{LO}$ et al. (1998), KLEIN (2003) e FITTIPALDI et al. (2003). A adição do anticorpo que se liga no sítio ativo da enzima Taq DNA Polimerase inibiu a presença de amplificações inespecíficas observadas na aplicação do teste em amostras de biopsia de tonsila, não afetando a amplificação nem a intensidade do produto de $715 \mathrm{pb}$, correspondente ao gene cpx do A. pleuropneumoniae.

Estas amplificações provavelmente são originadas de outros contaminantes presentes na microbiota das tonsilas, sendo que a quantidade de produtos inespecíficos varia de acordo com o meio utilizado no pré-cultivo das amostras e variam entre rebanhos (GRAM et al., 1996). Quando ocorre a ligação do anticorpo na enzima Taq DNA Polimerase, em temperatura ambiente, esta tem seu sítio ativo bloqueado durante a preparação da reação do teste da PCR, sendo desbloqueado somente após atingir a temperatura de desnaturação da fita de DNA $\left(94^{\circ} \mathrm{C}\right)$. Sendo assim, há redução de amplificações inespecíficas que, normalmente, ocorrem com temperaturas mais baixas e por este motivo este método é tipicamente utilizado para aumentar especificidade do teste (Invitrogen ${ }^{\mathrm{TM}}$ Life Technologies).

No teste de sensibilidade da PCRcpx, o limite de deteç̧ão médio de seis repetições foi de 675UFC na alíquota de DNA usada na PCR (correspondente a 1,35 $\mathrm{x} 105 \mathrm{UFC} \mathrm{mL}^{-1}$ ). Esta quantidade foi elevada quando comparada a $100 \mathrm{UFC} \mathrm{mL}^{-1}$, encontradas por LO et al. (1998), utilizando o mesmo iniciador. Neste teste, na sétima repetição, o limite detectado pela PCRcpx foi de 500UFC $\mathrm{mL}^{-1}$, entretanto, não foi considerado na média, uma vez que esta quantidade não foi detectada nas repetições anteriores, demonstrando que o teste pode detectar menor quantidade de células, porém, sem repetibilidade. Em registros utilizando teste de PCR convencional para detecção de $A$. pleuropneumoniae, o menor número de UFC $\mathrm{mL}^{-1}$ (50) foi detectado por GRAM e AHRENS (1998) utilizando iniciador para o gene omlA. Anteriormente, GRAM et al. (1996) haviam detectado 500UFC/mL utilizando iniciador universal. LO et al. (1998), com a PCR multiplex, detectaram 100UFC $\mathrm{mL}^{-1}$ de A. pleuropneumoniae. Porém, estes estudos não apresentam resultados de repetições do teste de sensibilidade. Segundo GRAM et al. (1996), valores tão baixos são difíceis de serem obtidos em testes diagnósticos, provavelmente como resultado da incompleta extração de DNA, inibição da DNA polimerase ou atividade de DNAse's em alguma etapa do procedimento.

$\mathrm{O}$ resultado do teste de especificidade mostrou que somente nas amostras referência de A. pleuropneumoniae foi visualizado um produto de $715 \mathrm{pb}$ e nenhum outro fragmento de amplificação foi observado nas amostras de outras espécies bacterianas utilizadas no teste, conforme constatado por KLEIN et al. (2003) e FITTIPALDI et al. (2003). A especificidade é essencial para a validação do resultado positivo. A partir deste resultado, é possível concluir que a técnica de PCR $c x$ apresenta alta especificidade, podendo ser aplicada na caracterização da espécie em casos clínicos de pleuropneumonia, considerando que, quando o resultado for negativo, outro teste diagnóstico deve ser utilizado para a identificação do sorotipo 4, uma vez que, segundo KUCHIISHI et al. (2005), este vem sendo isolado no Brasil.

O produto amplificado pela PCRcpx, proveniente de isolado de caso clínico, foi seqüenciado e apresentou similaridade de $93,39 \%$ com a seqüência do gene $c p x C B$ do A. pleuropneumoniae depositada no GenBank $^{\circledR}$ sob registro no- U36397 (GENBANK OVERVIEW), confirmando a especificidade do iniciador utilizado no teste para a detecção do agente. Embora com sensibilidade em nível abaixo do esperado, na maioria das repetições, $o$ iniciador apresenta alta especificidade.

Nos resultados da contaminação experimental de tecido tonsilar (Tabela 1), as suspensões bacterianas sem adição de tecido (T2 e T3) apresentaram resultados positivos em todas as repetições, independente da concentração bacteriana inicial no caldo $\mathrm{LB}\left(3,8 \times 10^{4} \mathrm{e} 3,8 \times 10^{1} \mathrm{UFC} \mathrm{mL}^{-1}\right.$, respectivamente). Os tratamentos à base de solução salina (T1) e com adição de tecido tonsilar (T4, T5 e T6), sem suspensão bacteriana, apresentaram resultados negativos em todas as repetições, conforme o esperado, demonstrando a especificidade do teste. 
Tabela 1 - Detecção de Actinobacillus pleuropneumoniae pela PCRcpx a partir diferentes concentrações bacterianas e número de porções de tecido tonsilar, presentes na amostra.

\begin{tabular}{|c|c|c|c|c|c|c|c|c|c|c|c|c|c|}
\hline \multirow{2}{*}{ Tratamento } & \multirow{2}{*}{ Material } & \multirow{2}{*}{ Porção de tecido } & \multirow{2}{*}{$\begin{array}{l}\text { Concentração bacteriana } \\
\text { (Inicial no LB) }\end{array}$} & \multicolumn{10}{|c|}{-----------Resultados (por repetição)------------ } \\
\hline & & & & $1^{\mathrm{a}}$ & $2^{\underline{\mathrm{a}}}$ & $3^{\mathrm{a}}$ & $4^{\mathrm{a}}$ & $5^{\mathrm{a}}$ & $6^{\mathrm{a}}$ & $7^{\text {a }}$ & $8^{\mathrm{a}}$ & $9^{\mathrm{a}}$ & $10^{\mathrm{a}}$ \\
\hline $\mathrm{T} 1$ & Salina & - & - & - & - & - & - & - & - & - & - & - & - \\
\hline $\mathrm{T} 2$ & Bactéria & - & $3,8 \times 10^{4} \mathrm{UFC} \mathrm{mL}^{-1}$ & + & + & + & + & + & + & + & + & + & + \\
\hline $\mathrm{T} 3$ & Bactéria & - & $3,8 \times 10^{1} \mathrm{UFC} \mathrm{mL}^{-1}$ & + & + & + & + & + & + & + & + & + & + \\
\hline $\mathrm{T} 4$ & & 1 & - & - & - & - & - & - & - & - & - & - & - \\
\hline $\mathrm{T} 5$ & & 2 & - & - & - & - & - & - & - & - & - & - & - \\
\hline T6 & & 3 & - & - & - & - & - & - & - & - & - & - & - \\
\hline $\mathrm{T} 7$ & & 1 & $3,8 \times 10^{4} \mathrm{UFC} \mathrm{mL} \mathrm{m}^{-1}$ & + & + & + & + & + & + & + & + & + & + \\
\hline $\mathrm{T} 8$ & Tecido & 2 & $7,6 \times 10^{4} \mathrm{UFC} \mathrm{mL} L^{-1}$ & + & + & + & + & + & + & + & + & + & + \\
\hline T9 & tonsilar & 3 & $1,1 \times 10^{5} \mathrm{UFC} \mathrm{mL}^{-1}$ & + & + & + & + & + & + & + & + & + & + \\
\hline $\mathrm{T} 10$ & & 1 & $3,8 \times 10^{1} \mathrm{UFC} \mathrm{mL} \mathrm{m}^{-1}$ & - & - & - & - & - & + & - & - & + & - \\
\hline $\mathrm{T} 11$ & & 2 & $7,6 \times 10^{1} \mathrm{UFC} \mathrm{mL}^{-1}$ & + & - & - & + & - & - & - & + & - & - \\
\hline $\mathrm{T} 12$ & & 3 & $1,1 \times 10^{2} \mathrm{UFC} \mathrm{mL}-1$ & - & + & + & - & - & - & + & - & + & + \\
\hline
\end{tabular}

A contaminação artificial de tonsila também demonstrou que, na presença de uma elevada concentração inicial de bactérias antes do pré-cultivo (T7, T8 e T9, contendo 3,8 X 104, 7,6 X $10^{4} \mathrm{e}$ $1,1 \times 10^{5} \mathrm{UFC} \mathrm{mL}^{-1}$, respectivamente), na presença de tecido tonsilar, todas as 10 repetições foram positivas na PCRcpx, indicando que o tecido não inibiu a amplificação. Quando foi reduzida a concentração inicial de bactérias antes do pré-cultivo (T10, T11 e T12, contendo $3,8 \times 10^{1}, 7,6 \times 10^{1}, 1,1 \times 10^{1} \mathrm{UFC} \mathrm{mL}^{-1}$, respectivamente), na presença de tecido tonsilar, foi observada a influência negativa do tecido pela inibição da amplificação da PCRcpx em 66,7\% (20/30 repetições) dos resultados. Embora as concentrações bacterianas iniciais estavam abaixo do limite de detecção do teste, após a etapa de pré-cultivo submetida, o número de bactérias aumentou para níveis detectáveis pelo teste.

Os resultados obtidos neste experimento indicam que houve efeito inibidor do tecido tonsilar na amplificação da PCRcpx e que foi, provavelmente, devido à presença de substâncias inibidoras presentes na amostra coletada, como enzimas e sangue. Esse resulatdo concorda com WILSON (1997), em um estudo dos fatores inibitórios das amplificações dos ácidos nucléicos, em que foi observado que esta técnica pode ser afetada pela presença de substâncias que podem interferir nos resultados do teste, na qual variam com o tipo de amostra testada, como também observado por SAVOYE et al. (2000), utilizando lavado traqueobronquial para deteç̧ão do A. pleuropneumoniae, além de sofrer a interferência da microbiota concomitante. Outros testes são necessários para verificação da inibição tecidual nos resultados da PCR e é importante o uso de controles internos para comprovação deste efeito, evitando assim resultados falsos negativos.

Embora a PCR apresente maior sensibilidade, quando comparada com métodos tradicionais de isolamento, este fato deve ser considerado na otimização da técnica. Por isso, a etapa de pré-enriquecimento em meio seletivo favorece o crescimento da bactéria-alvo, possibilitando maior número de detecção do agente em questão e reduzindo possíveis resultados falsos negativos.

Os resultados obtidos, nas diferentes etapas do estudo, indicam que a técnica otimizada em isolados de A. pleuropneumoniae para amostras de tecido animal é crítica. Para MØLLER et al.(1993), a biopsia de tecido tonsilar é o material de eleição na detecção do A. pleuropneumoniae, pois obtém melhores resultados quando comparado com suabe de tonsila e/ou cavidade nasal, porém, sofre influência dos efeitos inibidores de substâncias presentes do tecido tonsilar (WILSON, 1997) e depende do número de bactérias presentes na reação (FITTIPALDI et al., 2003). Para aumentar a população da bactéria-alvo pode ser utilizado um sistema de enriquecimento com meio de cultura seletivo LB que inibe a flora concorrente e favorece a detecção do agente, resultando em maior número de resultados positivos na PCR quando comparado com meios nãoseletivos (KUCHIISHI et al., 2003). Com relação à quantidade de material tonsilar por amostra, a menor quantidade de tecido tonsilar obtido pela biopsia possui proporcionalmente menor quantidade de bactérias (SAVOYE et al., 2000; FITTIPALDI etal., 2003). Este fato foi constatado no experimento realizado com contaminação artificial de tonsilas, em que o maior número de porções de tecido tonsilar utilizado 
proporcionou o aumento de resultados positivos na amplificação (T10, T11 e T12), sendo o número de reações positivas dois, três e cinco, respectivamente, observadas em 10 repetições. Estes resultados podem ser explicados pelo aumento no número inicial de bactérias, uma vez que os tratamentos 11 e 12 receberam, respectivamente, duas e três vezes mais bactérias do que o tratamento 10 , proporcionalmente ao número de porções de tonsila. Segundo MØLLER et al. (1993), mesmo com o efeito negativo do tecido tonsilar, este órgão continua sendo a amostra de eleição para identificação do A. pleuropneumoniae.

\section{CONCLUSÃO}

Os procedimentos adotados na otimização da técnica de PCRcpx reduziram a presença de amplificações inespecíficas observadas quando o teste foi aplicado em amostras clínicas.

Amostras de fragmentos de tecido tonsilar de infecção inicial ou com poucas células podem resultar em falsos negativos. A etapa de préenriquecimento bacteriológico da amostra, realizada anteriormente à técnica de PCRcpx, possibilita o aumento da população original, inibe a flora concorrente e favorece a detecção do agente, resultando em maior número de resultados positivos.

\section{REFERÊNCIAS}

BLAST. Basic Local Alignment and Search Tool. Capturado em 21 jan. 2005. Online. Disponível por: http:// www.ncbi.nlm.nih.gov/BLAST/.

FAN, H.H et al. Aplication of polymerase chain reaction with arbitrary to strain identification of Mycoplasma gallisepticum. Avian Diseases, v.39, p.729-735, 1995.

FENWICK, B.; HENRY, S. Porcine pleuropneumonia. Journal the American Veterinary Medical Association, v.204,n.9, p.1334-1340, 1994.

FITTIPALDI, N. et al. Evaluation and field validation of PCR tests for detection of Actinobacillus pleuropneumoniae in subclinically infected pigs. Journal of Clinical Microbiology, v.41, n.11, p.5085-5093, 2003.

GENBANK OVERWIEW. Capturado em 21 de jan. 2005. Online. Disponível em: http://www.ncbi.nlm.nih.gov/Genbank/ index.html.

GRAM, T. et al. Evaluation of a PCR for detectionof Actinobacillus pleuropneumoniae in mixed bacterial cultures from tonsils. Veterinary Microbiology, v.51, p.95-104, 1996.

GRAM, T.; AHRENS, P. Improved diagnostic PCR assay for Actinobacillus pleuropneumoniae based on the nucleotide sequence of an outer membrane lipoprotein. Journal of Clinical Microbiology, v.36, n.2, p.443-448, 1998.
HUNNEMAN, W.A. Incidence, economic effects, and control of Haemophilus pleuropneumoniae infections in pigs. Veterinary Quartely, v.8, n.1, p.83-87, 1986.

KLEIN, C.S. et al. Detection of Actinobacillus pleuropneumonie by PCR on field strains from healthy and diseased pigs. Current Microbiology, v.46, p.443-447, 2003.

KUCHIISHI, S.S. Avaliação de ensaio imunoenzimático indireto, isolamento bacteriológico tradicional e Reação em Cadeia da Polimerase no diagnóstico da pleuropneumonia suína. 2003. 72f. Dissertação (mestrado em Medicina Veterinária) - Curso de Pós-graduação em Clínica Médica Veterinária, Universidade Estadual Paulista.

KUCHIISHI, S.S. et al. Sorotipos de Actinobacillus pleuropneumoniae isolados no Brasil de 1993 a 2005 . In: CONGRESSO DA ABRAVES, 12, 2005, Fortaleza, CE. Anais... Fortaleza: Associação Brasileira de Veterinários Especialistas em Suínos, 2005. 576p. p.26-27.

LO, T.M. et al. Detection and identification of Actinobacillus pleuropneumoniae serotype 5 by multiplex PCR. Journal of Clinical Microbiology, v.36, p.1704-1710, 1998.

MACHADO, H.G. et al. Avaliação de testes de ELISA para o diagnóstico sorológico de infecções pelos sorotipos 3, 5 e 7 de Actinobacillus pleuropneumoniae em suínos. Arquivo Brasileiro de Medicina Veterinária e Zootecnia, v.53, n.5, p.513-522, 2001.

MØLLER, K. et al. Optimization of the detection of NAD dependent Pasteurellaceae from the respiratory tract of slaughterhouse pigs. Veterinary Microbiology, v.36, p.261$271,1993$.

MORES, N. et al. Estudo experimental a pleuropneumonia suína causada por Haemophilus pleuropneumoniae (Hpp). Patogenicidade e evolução das lesões anatomo-patológicas. Arquivo Brasileiro de Medicina Veterinária e Zootecnia, v.36, n.6, p.679-693, 1984.

MURDOCH, D.R. Nucleic acid amplification tests for the diagnosis of pneumonia. Medical Microbiology, n.36, p.11620-11700, 2003.

NICOLET, J. Actinobacillus pleuropneumoniae. In: LEMAN, et al. Diseases of swine. Iowa: Iowa State University, 1992. p.401-413.

PIJOAN, C. et al. Dilution technique for isolation of Haemophilus from swine lungs collected at slaughter. Journal of Clinical Microbiology, v.18, n.1, p.143-145, 1983.

SAMBROOK, J., RUSSELL, D. W. Molecular cloning: a laboratory manual. 3. ed. New York: Cold Spring Harbor Laboratory, 2001. 2344p.

SAVOYE, C. et al. A PCR assay used to study aerosol transmission of Actinobacillus pleuropneumoniae from samples of live pigs under experimental conditions. Veterinary Microbiology, v.73, p.337-347, 2000.

SIDIBÉ, M. et al. Detection of Actinobacillus pleuropneumoniae in the upper respiratory tract as a complement to serological tests. Canadian Journal of Veterinary Research, v.57, p.204-208, 1993.

TAYLOR, G.R. Polymerase Chain Reaction: basic principles and automation. In: MCPHERSON, M.J. et al. PCR: a practical approach. New York: Oxford University, 1993. p. $15-16$.

WILSON, I.G. Inhibition and facilitation of nucleic acid amplification. Applied Environment Microbiology, v.63, n.10, p.3741-3751, 1997. 